\title{
"Human Wreckage from Foreign Lands": A Study of the Ethnic Victims of the Alberta Sterilization Act
}

\author{
Ellen Keith
}

\begin{abstract}
On March $21^{\text {st }}, 1928$, the Alberta government passed the Alberta Sexual Sterilization Act. Between 1928 and 1972, the Alberta Eugenics Board used the Act to sterilize an estimated 2,822 'mentally-defective' Albertans. This paper examines the role that ethnicity played in the sterilization process, arguing that nativist attitudes influenced both the Canadian eugenics movement and the development of the Act.
\end{abstract}

Between 1928 and 1972, the Alberta Eugenics Board ordered an estimated 2,822 people sterilized under the Alberta Sexual Sterilization Act. ${ }^{1}$ The government-appointed Eugenics Board had labelled these people as 'feeble-minded,' or 'mentally-defective,' and decided that they were unfit to have children. The Act was an outcome of the Canadian eugenics movement, which became popular in the late nineteenth-century and was built on the foundations of Social Darwinism and the genetic theories put forth by Francis Galton. ${ }^{2}$ Eugenics is based on the belief that controlling reproduction can lead to the betterment of a race. Eugenicists target particular groups or individuals that they perceive as having desirable or undesirable qualities, a concept sometimes described as "positive" and "negative" eugenics. In order to determine to what degree ethnicity was an underlying factor in the sterilization of 'mentally-defective' patients, I will examine the Alberta Sexual Sterilization Act (herein referred to as "the Act"). I argue that, although the Act did not primarily target recent immigrants, the treatment of sterilization candidates did vary according to ethnic background. This ethnic discrimination was the product of nativist attitudes towards cultural differences, which were central to both the Canadian eugenics movement and the creation of the Act. Nativism refers to the idea that the interests of 'native' inhabitants should take precedence over those of recent immigrants. To develop this argument, I discuss the nativist aspect of the Canadian eugenics movement, outline the Act, and finally investigate the ethnic demographics of the sterilization candidates.

At the turn of the twentieth century, Canadians began to question their national identity in relation to recent social transformations such as urbanization and industrialization. At the heart of this identity crisis was the issue of immigration. Between 1896 and 1914, 3,000,000 immigrants came to Canada, and, in the first decade of the twentieth-century, about 800,000 of these immigrants were non-British. ${ }^{3}$ Many Canadians felt that these immigrants were changing the face of the nation by diluting British ideals. This problem was most noticeable in urban areas, where numerous languages other than English were spoken on the streets. In Toronto, for example, the number of non-English-speaking citizens grew by more than

\footnotetext{
1 There is some discrepancy regarding the sterilization statistics. For the purposes of this study, this figure will be used. See: Angus McLaren, Our Own Master Race: Eugenics in Canada, 1885-1945, (Toronto: McClelland \& Stewart Inc., 1990), 159.

${ }^{2}$ The history of eugenics will not be described in detail in this study. For further information, see McLaren, Our Own Master Race.

${ }^{3}$ McLaren, Our Own Master Race, 47.
} 
400\% between 1900 and $1911 .{ }^{4}$ Because they were visible minorities and marginalized in society, immigrants became linked to the social problems that arose out of urbanization, such as prostitution and alcoholism. Some people criticized the different cultural values and practices of certain 'ethnic' immigrants. This led to the reinforcement of a racial hierarchy in Canada. J.S. Woodsworth, a prominent member of the Social Gospel movement, promoted this hierarchy in his 1909 book, Strangers Within Our Gates. ${ }^{5}$ Here, he addressed the need for assimilation and "quality immigrants." In his mind, this meant groups like Anglo-Saxons and Scandinavians, and not Slavs or Galicians, whom he described as "animalized" and "addicted to drunken sprees." Although Woodsworth was, in fact, involved in poor relief in Winnipeg, his comments here illustrate underlying nativist attitudes dehumanized certain ethnic groups.

This dehumanization was the first step in linking the eugenics movement to the issue of immigration. By the outbreak of the First World War, many people became involved in a debate about the changing nature of the Canadian population. Eugenicists identified two threats to Canadian well-being and mental health: the 'feeble-minded' and 'mentallydefective' inherent in Canadian society; and the influx of undesirable immigrants. ${ }^{7}$ Many Canadians felt that Britain and other nations were dumping their criminals and "degenerates" on Canada. Eugenicists fostered this belief by pointing to increasing crime rates among immigrant groups. ${ }^{8}$ At this time, criminality was associated with immorality and mental defectiveness. ' By playing up the connection between immigrants and crime, eugenicists implied that immigrants were mentally-defective. To support this idea, they made assertions about the demographic makeup of patients in Canadian mental health institutions. Helen MacMurchy, a prominent eugenics activist, stated, "It is well known to every intelligent Canadian ... that the number of recent immigrants who drift into institutions for the neuropathic, the feeble-minded and the insane is very great." In 1914, MacMurchy believed that Canada was letting in at least 1,000 'feeble-minded' immigrants each year. ${ }^{10}$ Charles K. Clarke, a distinguished Canadian physician, agreed with MacMurchy. He felt that the most degenerate immigrants came from Eastern and Central Europe, and advocated an immigration system that would filter out 'mentally-defective' and other undesirable immigrants. ${ }^{11}$

These eugenicists argued that the restriction of immigration was essential to the elimination of 'mentally-defective' offspring. They felt that social problems related to immigrants were connected to the traits of the individual. These traits had a negative effect on the development of the nation, especially because of the high fertility rate of some of these immigrant groups. However, the eugenicists did not want to be labelled as racists, so they

\footnotetext{
${ }^{4}$ Ian Robert Dowbiggin, Keeping America Sane: Psychiatry and Eugenics in the United States and Canada, 1880-1940, (Ithaca, New York: Cornell University Press, 1997), 136.

${ }^{5}$ J.S. Woodsworth, Strangers Within Our Gates: or Coming Canadians, (Toronto: F.C. Stephenson, 1909$), 136$.

${ }^{6}$ McLaren, Our Own Master Race, 47.

${ }^{7}$ Dowbiggin, Keeping America Sane, 133.

8 McLaren, Our Own Master Race, 52.

${ }^{9}$ In 1929, the Canadian Council on Child Welfare reported that the feeble-mindedness of immigrants was responsible for crime, filth, and immorality in Canada. See: Walker Barrington, The History of Immigration and Racism in Canada, (Toronto: Canadian Scholars' Press, 2008), 199.

10 This quote can be found in Ibid., 46, 51. MacMurchy based her estimation on calculations by Dr. Henry H. Goddard, an employee at an American school for the feeble-minded.

${ }^{11}$ Dowbiggin, Keeping America Sane: 142.
} 
insisted that selective immigration would be based on a scientific analysis of acceptable individuals. In reality, they largely based their decisions about the value of potential immigrants on the ability of these immigrants to conform to culturally acceptable (i.e., British) behaviour. ${ }^{12}$ Nonetheless, eugenicists' attempts to limit immigration were countered by the practical concerns of big businesses wanting cheap labour, and the federal government, which was focused on filling the West with vast numbers of immigrants. This situation changed in 1905, when Frank Oliver took over from Clifford Sifton as Minister of the Interior. Oliver criticized Sifton's willingness to focus on the quantity, rather than what he believed was the quality, of the immigrants. In 1906 and 1910, Oliver had changes made to the Immigration Act which barred 'mental-defectives' and other undesirables from immigrating to Canada. Also, immigrants who ended up in a publicly-funded charitable facility (such as a mental institution) within two years of their arrival could be deported. Despite this, the deportation process was complex and difficult to coordinate. Deportations required extensive paperwork, and were often time-consuming. Additionally, doctors were employed to screen new immigrants, but this proved to be an inefficient system. Medical inspections at ports of entry were often rushed. ${ }^{13}$ The ineffectiveness of immigration restrictions compelled some Canadians to consider another way to control the perceived threat of 'feeble-minded' immigrants - sterilization.

Historian Ian Robert Dowbiggin contends that the large immigrant population on the prairies accelerated the eugenics movement in Alberta. The province could not exert control over immigration affairs, but sterilization offered an alternative solution to the problem of 'mentally-defective' immigrants. Sterilization also seemed to promise behavioural changes in the immigrants. This would have appealed to the social reformers in Alberta, who also sought to modify the behaviour and perceived immorality of immigrants. ${ }^{14}$ The multitude of immigrants and the strong influence of other reform movements contributed to the popularity of the eugenics movement in Alberta.

The Alberta eugenics movement expanded in 1921 with the Canadian National Committee for Mental Hygiene's (CNCMH) publication of a survey on mental health in Alberta. The survey addressed the problem of mental-defectiveness in the province and the effects of immigration on mental health. The executor of the survey, Dr. Clarence Hincks, stressed the importance of monitoring the quality of incoming immigrants. According to his findings, 48.08\% of Albertans in 1916 were Canadian-born. However, he wrote that:

... [T] heir proportion [was] considerably less in the Mental Hospital, Ponoka, the jails and the institutions caring for unmarried mothers. In other words, immigrants $[\ldots]$ contributed more than their fair share to the insane and feeble-minded population, and to other undesirable groups..$^{15}$

While his observations on the makeup of the institutions were likely accurate, his interpretation of these demographics was erroneous. Hincks credited much of the mental

\footnotetext{
12 McLaren, Our Own Master Race, 49.

13 The abundance of immigrants and a shortage of medical staff meant that, in practice, the questioning period was quick, and examinations were not always up to immigration standards. Information in this paragraph on immigration laws can be found in Ibid., 56; Dowbiggin, Keeping America Sane: 147-178.

14 Ibid., 135.

15 Tim Christian, "The Mentally Ill and Human Rights in Alberta: A Study of the Alberta Sexual Sterilization Act" (Ph.D. diss., University of Alberta, 1973), 6.
}

Constellations

Volume 2, No. 2 (Winter 2011) 
illness in Alberta to a recent influx of Slavic immigrants. He failed to consider the possibility that this illness could have been a symptom of the confusion and challenges of assimilation into a new world. Recent immigrants did not have the familial networks to support them in times of illness, and may have been more likely to end up in institutions. Instead, Hincks attributed this illness to heredity traits passed down through generations of Slavs. ${ }^{16}$

The results of this survey garnered significant attention among Alberta reformers and politicians. The United Farmers of Alberta (UFA) and the United Farm Women of Alberta (UFWA) used the survey to advance their proposal for sterilization legislation. The UFWA was especially concerned with the well-being of Alberta children, who they felt were threatened by 'mentally-defective' immigrants and their related social problems. One UFWA woman stated:

We would do well to keep clearly before us the percentage of mental defectives in Alberta who were not of Canadian stock. The figures are positively startling; of the 130 patients in the Provincial Training School, December 1924, but 24\% were Canadian stock. In other words, fully $75 \%$ of the mental-defectives at the Red Deer school are of the stock brought into Canada by immigration. ${ }^{17}$

In order to combat this perceived "plague of defective immigrants," the UFWA lobbied for a eugenic sterilization program based on selective breeding practices on farms.

In response to UFWA lobbying and public support, the Alberta Legislative Assembly passed the Alberta Sexual Sterilization Act on March 21, 1928, with 34 votes in favour, and eleven in opposition. ${ }^{18}$ The Act was designed to facilitate patients' adaptation to the outside world as they were discharged from mental health institutions. Sterilization was an alternative to segregation; the 'mentally-defective' could live among the general population as long as they did not pose a threat to society. As the Act explained, sterilization would ensure that, the "risk of multiplication of the evil by transmission of the disability to progeny [was] eliminated." "19 Medical experts were confident that they could impede the spread of mental illness by controlling reproduction. Supporters of the Act believed that sterilization would also have other social and economic benefits. In 1932, Emily Murphy published an article in the Vancouver Sun in an attempt to promote the Act. In addition to controlling the reproduction of the so-called "human wreckage that [had] been dumped from foreign lands," she claimed that sterilization would modify behaviour. ${ }^{20}$ If male patients were sterilized, their morality would increase and they would be less likely to sexually harass women and children. Murphy also noted that sterilizing patients and integrating them into mainstream society would lower the financial burden of these people on the province. By highlighting the social consequences of sterilization, the government and eugenics activists brought the matter of reproduction out of the private realm and turned it into an issue of grave public importance.

\footnotetext{
16 McLaren, Our Own Master Race, 99.

17 Whiting, The Sterilization of Leilani Muir, 1997.

${ }^{18}$ Christian, "The Mentally Ill and Human Rights in Alberta," 20.

${ }^{19}$ See: Legislative Assembly Alberta, The Sexual Sterilization Act, (Edmonton, Alberta: Provincial Government of Alberta, 1928)

${ }^{20}$ Emily Murphy, "Sterilization of the Insane," The Vancouver Sun 1932.
} 
In order to control and monitor all decisions regarding sterilization, the Act created a fourmember Eugenics Board. Mental health institutions from around the province could send potential sterilization candidates to the Board for deliberation. According to Margaret Thompson, a former board member, the Board examined each case with two main questions in mind: would this patient make a 'good' parent. according to British-Canadian ideas of parenting, and would they transfer their biological defects to any offspring? ? $^{21}$ The Board used psychiatric evaluations, I.Q. test scores, and the patients' personal histories (which included their ethnic backgrounds) to answer these two questions and either approve or reject the proposal for sterilization. Initially, the Board's authority was limited by a patient consent clause, which required patient authorization (or that of a parent or guardian, who, in many cases, may have initially advocated the institutionalization of the patient), for sterilization treatment. In 1937, the Act was amended so that consent was no longer a requirement for 'mentally-defective' patients. This amendment increased both the efficiency and number of sterilizations. Angus McLaren estimates that, over a period of 44 years, 4,725 candidates were presented to the Board, of which $60 \%$ were ultimately sterilized. ${ }^{22}$ The question at hand is whether these sterilizations targeted immigrant and ethnic groups, as one would expect based on the nativist discourse of the Canadian eugenics movement.

As previously stated, the Board relied heavily on I.Q. tests in their examination of sterilization candidates. In spite of this, approximately one-third of the cases were decided without the use of I.Q. tests. In these cases, the Board would have to place more emphasis on the patient's personal background. Personal histories included information about the patient's ethnicity, family, education, religion, etc... ${ }^{23}$ Here, the dissertations of Tim Christian and Jana Marie Grekul are invaluable sources for an analysis of the demographics of the victims. ${ }^{24}$ There is some discrepancy in their statistics, but overall their results are very consistent. Due to space constraints, I will only explicitly make reference to Christian's more extensive data in this analysis.

When it comes to the birthplace of the victims, it appears that there is no actually strong connection between immigration and sterilization. A great majority $(81 \%)$ of the individuals studied were Canadian-born, although this proportion varied by decade. ${ }^{25}$ Overall, immigrants were actually under-represented in the sterilization accounts, when compared to their presence in the general population. Still, the minutes from the Eugenics Board indicate that immigration was a contentious issue with regards to sterilization. On May 21, 1935, the Board noted that, "In view of the number of deportable cases, among the patients presented to the Board, many of whom refuse consent for sterilization, the Board agreed that a recommendation be sent to the government, that steps be taken to deport as many as

\footnotetext{
${ }^{21}$ Margaret Thompson became involved with the Eugenics Board in 1960, because of her work with genetics at the University of Alberta. See: Glynis Whiting, The Sterilization of Leilani Muir, National Film Board of Canada, (Montreal: National Film Board of Canada, 1997)

22 McLaren, Our Own Master Race, 159.

23 Jana Marie Grekul, "The Social Construction of the Feebleminded Threat: Implementation of the Sexual Sterilization Act in Alberta, 1929-1972" (Ph.D. diss., University of Alberta, 2002), 122.

${ }^{24}$ Both use a "one-in-five" sampling technique to study the victims. For example, Christian bases his statistics on a random selection of patients during five, five-year periods. See: Christian, "The Mentally Ill and Human Rights in Alberta."

25 Over time, the proportion of immigrants presented to the Board decreased. This decrease does not correspond to the post-war immigration boom, but may relate to the eventual decline in immigration. Christian, "The Mentally Ill and Human Rights in Alberta," 99; Grekul, "The Social Construction of the Feebleminded Threat," 113.
} 
possible of these cases." ${ }^{26}$ This suggests that immigrants were exercising some agency by refusing sterilization, and may account for the weak connection between sterilization data and immigrants. However, during the Depression, deportation was a means for getting rid of many types of "undesirable" people, not just immigrants.

An examination of the ethnic background of the victims provides more conclusive results. Christian separates the ethnic backgrounds of his study sample into seven categories: British, American, East European, West European, First Nations/Métis, French Canadian, and Other. To compare the ethnic makeup of the sterilization candidates, he first notes the proportion of patients from each ethnic group that were presented to and passed by the Board, before looking at those patients who were actually sterilized. Finally, he compares these proportions to the ethnic makeup of the general Alberta population. His data is reproduced in the Appendix of this paper. ${ }^{27}$

Christian's results indicate a clear prejudice towards certain ethnic groups. ${ }^{28}$ These groups were disproportionately represented in relation to the Alberta population. Patients of British background constituted the largest ethnic group of sterilization candidates, with $32.8 \%$ of these patients presented to the Board. However, British-Canadians made up $48.8 \%$ of the Alberta population, so they were actually drastically under-represented in the sterilization process. The number of British-Canadian patients that were actually sterilized was also disproportionately low, relative to the number approved for sterilization. Western European data reveals a similar trend, but this pattern is reversed for East European and First Nations or Métis groups, which were over-represented in the sterilization cases. With the first four years of the Act as an exception, the percentage of people of East European ethnicity that were both approved and sterilized was continuously higher than their corresponding presence in the provincial population. The statistics regarding First Nations and Métis victims show the most discord with Alberta census data. This group was highly overrepresented in the sterilizations, especially in the final five years of the Act, during which proportionately more First Nations or Métis were sterilized than British-Canadians. During this period, First Nations or Métis patients constituted one-quarter of the sterilizations, even though only $3.4 \%$ of Alberta's population belonged to this ethnic group. There was also an increase in the proportion of First Nations and Métis candidates presented to the Board over time. Furthermore, First Nation and Métis patients had a $75 \%$ chance of being actually sterilized once they were approved, which made them the group most likely to ultimately be sterilized. ${ }^{29}$

It is easy to assume that the Board and the medical personnel involved in the sterilization process were racist, and openly discriminated against some groups because of their ethnicity. Indeed, Thompson recognized that eugenicists based their categorization of desirable and

\footnotetext{
26 Ibid., 155.

27 See Appendix. It is worth noting that the provincial census data on Americans, "Others," and FrenchCanadians is missing in Table One. Because of insufficient data, it is difficult to draw conclusions about the sterilization of other ethnic groups, such as the Asian and African American populations in Canada. This presents a limitation to the study, and consequently, these ethnic groups are not the focus of this analysis. ${ }_{28}$ Please consult the appendix of this paper for a reproduction of Christian's data as discussed in this paragraph.

${ }^{29}$ Grekul, "The Social Construction of the Feebleminded Threat," 116. The specific results of Grekul's study will not be explicitly stated here, due to space constraints. However, her data reveals the same trends.
} 
undesirable traits on some level of personal bias. ${ }^{30}$ Still, one must remember that the Board used I.Q. test results in two-thirds of the cases. For example, Leilani Muir was sterilized after scoring 64 on an I.Q. test. ${ }^{31}$ Yet, the reliance on I.Q. scores has ethnic implications in itself. East European and Métis or First Nations patients generally scored much lower on the socalled 'objective' I.Q. tests than West European and British patients. On average, $62.2 \%$ of East Europeans scored between 36 and 70, and only 8.1\% scored above 70. (The average I.Q. is 100.) In comparison, 90.9\% of First Nations and Métis scored between 36 and 70. Modern studies have revealed that I.Q. questions tend to cater to a certain set of cultural understandings and values, which may be difficult for members of different cultures to understand. ${ }^{32}$ Culturally-based problems with I.Q. testing would be minimal for most British Canadians, but could have serious implications for unassimilated First Nations peoples, as well as non-English speaking immigrants and their first-generation Canadian offspring. The relationship between ethnicity and I.Q. tests is intriguing, but cannot explain the ethnic demographics of the sterilization victims on its own. Too many people without I.Q. scores were sterilized, and it is unlikely that I.Q. was ever the sole determinant in a sterilization case. To some extent, patients must have been treated differently in according to their ethnic background.

In 1971, a new Progressive Conservative government rose to power in Alberta. One of Premier Peter Lougheed's first acts in office was to end the sexual sterilization program, and in 1972, the Act was repealed. As the recent number of victim settlement cases has shown, the effects of the Act were in many cases long-term and life-changing. For 44 years, a fourmember Board had the power to 'play God' and define a select set of societal norms. Whether or not the Board members consciously discriminated against these patients on an ethnic basis is difficult to say. Although the Act did not primarily affect immigrants, it had a widespread impact on people of ethnic groups that did not conform to the mainstream Anglo-Saxon conceptions of cultural acceptability. The ethnic bias of the victim demographics reflects a continuation and manifestation of the racial hierarchy and nativist attitudes that shaped the Canadian eugenics movement, and led to the creation of the Act in the first place. When the Act was repealed in 1972, Albertans finally began to push away from ethnocentric notions of normality, and, in doing so, prepared themselves to embrace a new, multicultural Canadian identity.

\footnotetext{
${ }^{30}$ K. G. McWhirter and J. Weijer, "The Alberta Sterilization Act: A Genetic Critique," The University of Toronto

Law Journal 19, no. 3 (1969): pp. 424-431.

${ }^{31}$ Heather Pringle, "Alberta Barren: The Mannings and Forced Sterilization in Canada," Saturday Night, no. June (1997): November 20th, 2010.

32 Christian, "The Mentally Ill and Human Rights in Alberta," 120.
} 


\section{Appendix}

\section{Table 1:}

\begin{tabular}{|c|c|c|c|}
\hline Race Origin & Number Presented & Percent Presented & Percent of Population \\
\hline British & 128 & 32.8 & 48.8 \\
\hline American & 12 & 3.1 & Missing Data \\
\hline East European & 83 & 21.3 & 16.0 \\
\hline Indian or Métis & 32 & 8.2 & 2.5 \\
\hline Other & 6 & 1.5 & Missing Data \\
\hline West European & 88 & 22.6 & 31.6 \\
\hline French-Canadian & 15 & 3.8 & Missing Data \\
\hline Not Recorded & 40 & Missing Data & Missing Data \\
\hline
\end{tabular}

Table 37 in Christian, "The Mentally Ill and Human Rights in Alberta," 85.

\section{Table 2:}

The Percentage of Persons of Several Ethnic Backgrounds in the Alberta Population, in the Population of Patients Presented to and Passed by the Eugenics Board, and in the Population of Patients Sterilized

\begin{tabular}{|l|l|l|l|l|l|l|l|l|l|l|l|l|l|}
$\begin{array}{l}\text { Time } \\
\text { Frame }\end{array}$ & \multicolumn{3}{l|}{ British } & \multicolumn{3}{|l|}{ East European } & \multicolumn{3}{l}{ Indian or Métis } & \multicolumn{3}{l}{ West European } \\
\hline & Pop. & Pres. & Steril. & Pop. & Pres. & Steril. & Pop. & Pres. & Steril. & Pop. & Pres. & Steril. \\
\hline $\begin{array}{l}1929- \\
1933\end{array}$ & 53.2 & 37.2 & 33.3 & 15.5 & 14 & 14.3 & 2.0 & 7.0 & 7.1 & 28.3 & 20.9 & 11.9 \\
\hline $\begin{array}{l}1939- \\
1943\end{array}$ & 50.2 & 41.8 & 29.7 & 15.4 & 29.1 & 35.1 & 2.7 & 3.6 & 5.4 & 31.0 & 20.9 & 24.3 \\
\hline $\begin{array}{l}1949- \\
1953\end{array}$ & 48.7 & 25.8 & 30.4 & 16.6 & 22.7 & 21.7 & -- & 4.5 & 4.3 & 30.7 & 42.4 & 34.8 \\
\hline $\begin{array}{l}1959- \\
1963\end{array}$ & 45.2 & 40.4 & 34.5 & 16.6 & 21.2 & 20.7 & 2.1 & 12.1 & 13.8 & 33.9 & 19.2 & 13.8 \\
\hline $\begin{array}{l}1969- \\
1972\end{array}$ & 46.8 & 22.5 & 22.9 & 16.2 & 22.5 & 20.0 & 3.4 & 25.0 & 25.7 & 34.4 & 22.5 & 14.3 \\
\hline
\end{tabular}

Pop. = Population in Alberta

Pres. $=$ Patients presented to and approved by the Board

Steril. $=$ Patients sterilized

Table 40 in Christian, "The Mentally Ill and Human Rights in Alberta," 88. 


\section{Bibliography}

Alberta, Legislative Assembly. The Sexual Sterilization Act. Edmonton, Alberta: Provincial Government of Alberta, 1928.

Barr, Allison. Eugenics in Alberta: The Lasting Effects. Undergraduate Paper for History 488, Dr. Mullally ed. 2009.

Barrington, Walker. The History of Immigration and Racism in Canada. Toronto: Canadian Scholars' Press, 2008.

Christian, Tim. "The Mentally Ill and Human Rights in Alberta: A Study of the Alberta Sexual Sterilization Act.” Ph.D. diss., University of Alberta, 1973.

Dowbiggin, Ian Robert. Keeping America Sane: Psychiatry and Eugenics in the United States and Canada, 1880-1940. Ithaca, New York: Cornell University Press, 1997.

Grekul, Jana Marie. "The Social Construction of the Feebleminded Threat: Implementation of the Sexual Sterilization Act in Alberta, 1929-1972.” Ph.D. diss., University of Alberta, 2002.

Hodson, C. B. S. "Sterilization of the Feeble Minded." The British Medical Journal 1, no. 3515 (1928): 878-879.

---. "Sterilization of the Feeble-Minded in Alberta." The British Medical Journal 1, no. 3511 (1928): 680.

McLaren, Angus. Our Own Master Race: Eugenics in Canada, 1885-1945. Toronto: McClelland \& Stewart Inc., 1990.

McWhirter, K. G., and J. Weijer. "The Alberta Sterilization Act: A Genetic Critique.” The University of Toronto Law Journal 19, no. 3 (1969): 424-431.

Murphy, Emily. Sterilization of the Insane. The Heritage Community Foundation: The Vancouver Sun, 1932.

Pringle, Heather. “Alberta Barren: The Mannings and Forced Sterilization in Canada.” Saturday Night (June 1997): Accessed November 20th, 2010.

Wahlsten, Douglas. "Eugenics and Politics: Science and Politics (In the 1950s)" Living Archives on Eugenics Conference. The University of Alberta, Edmonton. 22 October, 2010.

Whiting, Glynis. The Sterilization of Leilani Muir. Edited by National Film Board of Canada. Montreal: National Film Board of Canada, 1997. 